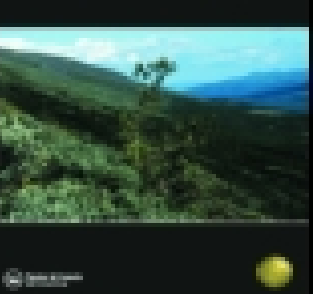

ISSN: 0374-6607 (Print) (Online) Journal homepage: http://www.tandfonline.com/loi/tped18

\title{
Notes of a Tour in the Engadine, with a List of Alpine Plants
}

\author{
James Blaikie Her Majesty's Inspector of Schools M.A. F.R.S.E.
}

To cite this article: James Blaikie Her Majesty's Inspector of Schools M.A. F.R.S.E. (1883) Notes of a Tour in the Engadine, with a List of Alpine Plants, Transactions of the Botanical Society of Edinburgh, 14:1-4, 74-79, DOI: 10.1080/03746608309468394

To link to this article: http://dx.doi.org/10.1080/03746608309468394

册 Published online: 01 Dec 2010.

Submit your article to this journal $\widetilde{x}$

Џ Article views: 2

Q View related articles $₫$ 
Notes of a Tour in the Engadine, with a List of Alpine Plants. By James Blalkie, M.A., F.R.S.E., Her Majesty's Inspector of Schools.

(Read 12th February 1880.)

The Engadine (Engiadina in Romaunsch) or upper valley of the Inn is situated in the extreme south-east corner of Switzerland. The Inn rises in the lake of Sils, and flows in a comparatively straight course north-eastwards to join the Danube. This lake is about 6000 feet above the sea, and, after leaving it, the Inn forms the lakes of Silva Plana and San Moritz, so that the upper part of the valley is nearly level. To those who, like my wife and myself, first enter this valley from the Italian side, by crossing the picturesque Maloja Pass, the effect is very striking. It is a long flat grassy plain, bounded on both sides by snow-capped hills; no trees or corn are at first to be seen, and birds are rarely heard. Farther down we come on the Pinus cimbra and the larch, and small patches of barley and rye, but wheat does not ripen in any part of the Engadine.

The air is dry and invigorating, and hence it has lately become a favourite resort of both tourists and invalids. The high elevation places mountain and glacier excursions within the reach of all, while the rich Alpine Flora affords a never-ending source of interest and enjoyment. Our first visit was paid late in September. The flowers were over, but here and there a Gentian or a Phyteuma still showed their dainty blossoms, and we determined that when an occasion arrived we should revisit the Fngadine earlier in the season. Accordingly, on the 11th of August 1879, we set out from Chur (Coire), and walked to the Engadine, over the Parpan and Albula Passes. On the Albula, after passing through a weird and desolate hollow, strewed with lichen-covered rocks, called the Teufelsthal, wo suddenly found ourselves on a grassy meadow surrounded by exquisite Alpine plants. Among other's were-

Saxifraga oppositifulia.

Arenaria bifiora.

Dryas octopetala.

Androsace Chamæjasme.
Primula farinosa.

Ranunculus alpestris.

Gentiana acaulis. 
Captivated by their beauty, we determined to take home specimens of as many as possible, and at Samaden, the principal village of the Engadine, we purchased boards, paper, Hallier's edition of Koch's "Flora," and Weber's coloured pictures of Alpine plants. Unfortunately, the idea of making a complete botanical collection did not at first occur to us, and our list of plants will be found incomplete, inasmuch as it omits cryptogams, grasses, sedges, \&c., and some plants which are either common at home or were too bulky to make pretty specimens.

At Samaden the Inn is joined by a considerable streamthe Flatz, or Bernina Bach-and the tourist may either proceed up the Inn to San Moritz, celebrated for its mineral waters, and a great resort of invalids, or by the steeper Bernina Valley to Poıtresina.

Pontresina is admirably situated as a centre for Alpine excursions. To the westward, in the angle formed by the Inn and the Flatz, rise the glorious group of the Bernina Alps. The highest point, Piz Bernina, is 13,300 feet, and the ascent, though difficult, is often made. Two great glaciers, the Rosegg and the Morteratseh, stretch far down towards the Flatz valley, and form highways by which man penetrates these vast solitudes. On the eastern side of the valley Piz Languard (10,700 feet) and other mountains offer climbing, without either the attraction or the danger of ice, and are clothed in many parts with a rich and varied Flora. Less ambitious persons have only to cross the stream to enjoy shady walks, where the banks under the trees are carpeted with the creeping stems and tender piụklined cups of the Linnoea borealis.

One morning I left Pontresina at 4 A.M., along with a friend, who was both a bold and cautious mountainer and an accomplished botanist, and walked to Samaden, in order to climb Piz Ot (the high peak) a superb granite pyramid, whose summit reaches 10,650 feet above the sea.

Leaving the village, we passed first through closely mown meadows, where the lilac buds of Colchicum autumnale were beginning to peep through the ground. Higher up among the long grass grew the showy blossoms of Dianthus superbus and Knautia sylvatica. Still higher up was Gentiana campestris, both purple and white, and when the shoulder of the 
hill was turned, we came on a grassy flat which abounded in Nigritella angustifolia, Dryas octopetala, Viola calcarata, Silene acaulis, Gentiana bavarica, Phyteuma hemisphoricum, and other plants.

Before us lay the peak of the hill, apparently a granite mass, unrelieved by even a blade of grass; but as we climbed we found many a tiny plant clinging to the rocky wall. We reached the top about ten o'clock, and enjoyed a magnificent view of the surrounding mountains. Presently, we observed what seemed to be a path descending the northern side of the hill, and as it occurred to us that this must lead to the Bevers Valley, celebrated for its beauty, and interesting botanically, we determined to follow it.

We had not gone far before we began to doubt the wisdom of our resolution. The path stopped short at a rock which overhung a vertical precipice. What we had taken for a path was, in fact, a stone couloir, ending in a stone cascade.

But the rocks around us formed a garden where the most characteristic Alpine flowers blossomed with singular luxuriance.

These wonderful little plants, nearly all peremial, and sometimes less than an inch in length, growing in rnossy tufts in the interstices of the rocks, defy alike the burning sun of summer and the severest frost of winter, and expand their tiny blossoms with unfailing regularity, in many places rarely seen by human eye.

Here we obtained Geum montanum and Geum reptans, the pure white blossoms of the newly expanded Ranunculus glacialis, and the rose-coloured blossoms of the same flower at a later stage, the pretty pink tufts of Dianthus glacialis, the deep blue of Eritrichium nanum, and the dainty pink and white Androsace glacialis. Less conspicuous, but even more interesting, from their characteristically Alpine growth, were Phyteuma pauciflorum, and the saxifrages. Of the latter, we obtained-

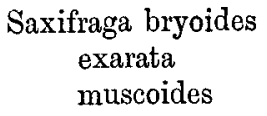

$$
\mid \begin{gathered}
\text { Saxifraga stenopetala } \\
\text { Seguieri } \\
\text { planifolia }
\end{gathered}
$$

As we gazed with wonder around, a chamois made its appearance, and, surprised at the unexpected intrusion, 
sprang from rock to rock along the face of the precipice, passing only a few yards from us. This piece of good luck, as well as the botanical treasures we had found, encouraged us to continue our difficult descent. With a good deal of trouble we at last reached a steep slope of snow, down which we glissaded, and, crossing the glacier without adventure, descended a second cliff into the Bevers Valley.

Here we found Gentiana punctata, large quantities of which had been cut down by the peasants, probably with a view to its use in Materia Medica. In one rocky gully Pedicularis atro-purpurea was expanding luxuriantly its fern-like foliage. Further down, a great variety of Aconites, blue, variegated, and yellow, were growing along with Senecio sarracenicus, and many other plants. After a long walk we returned to Pontresina.

Another excursion which proved botanically interesting, was that to the $V a l$ del Fain (or Hay Valley), which opens into the Bernina Valley, not far from the pass. The mountains on both sides of this valley consist of limestone. Here we found Lilium Martagon, Aquilegia alpina, Gentiana lutea, Campanula thyrsoidea, Helianthemum vulgare and relandicum, Sempervivum arachnoidenm, Wulfeni and (I think) Brownii, Gnaphalium leontopodium (the celebrated Edelweiss), Senecio abrotanifolius, Aronicum scorpioides, Ranunculus montanus, Papaver alpinum, Phyteuma humile, with several cruciferous, leguminous, and other plants.

Our return journey was made from the Engadine to Davos by the Scaletta Pass, and from Davos to Chur by the Strela; both these passes are crossed only by footpaths. Our dried specimens were sent round by coach; those in process of drying we carried with us. We found very frequent changes of paper the best means of preserving the natural colours of the plants. We had particular difficulty with Dryas octopetala, but at last succeeded in inducing one specimen to remain white, the campanulas were obstinate to the last.

List of Dried Specimens of Plants from the Engadine.*

Colchicum autumnale, $L$ MONOCOTYLEDONS.

Veratrum album, $L$. Lilium Martagon, $L$.

Lloydia serotina, Salisb. Allium Victorialis, $\boldsymbol{L}$. Orchis globosa, $L$. latifolia, $L$.

* The arrangement is that adopted in Hallier's edition of Koch's "Flora Germanica." 
Gymnadenia conopsea, R. Brown. odoratissima, Richard.

Nigritella angustifolia, Richard. Eriophorum angustifolium, Roth. Poa alpina (vivipara), $L$.

\section{DICOTYLEDONS.}

Thesium alpinum, $L$.

Oxyria digyna, campdera ( $=$ reniformis, Hooker).

Polygonum Bistorta, $L$. viviparum, $L$

Salix lerbacea, $L$.

Daphne striata, Trattinnick.

Thalictrum aquilegifolium, $L$. alpinum, $L$.

Anemone alpina (sulphurea), $L$.

Ranunculus alpestris, $L$. rutefolius, $L$.

glacialis, $L$.

montanus, willd.

acris, $L$.

nemorosus, $D C$

Caltha palustris, $L$.

Aquilegia alpina, $L$.

Aconitum Napellus, $L$. paniculatum, Lam. Lyeoctonum, $L$

Gypsophila repens, $L$.

Dianthus glacialis, Hünke. sylvestris, Wulfen. deltoides, $L$. superbus, $L$.

Saponaria ocymoides, $L$.

Silene nutans, $L$. inflata, Smith acaulis, $L$. rupestris, $L$.

Lyehnis diurna, Sibthorp. flos-cuculi, $L$.

Lepigonum rubrum, Wahlenb.

Alsine recurva, Wahlenb.

Arenaria biflora, $L$.

Stellaria nemorum, $L$.

Cerastium latifolium, $L$. arvense, $L$

Helianthemum vulgare, Gärtner. celandicum, Wahlenb.

Viola biflora, $L$. tricolor, $L$.

lutea, Smith

calcarata, $L$.

Zoysii, Wulf.

Parnassia palustris, $L$.

Papaver alpinum, $L$.

Nasturtium palustre, $D C$.

Arabis alpina, $L$. auriculata, Lam. bellidifolia, Jacq.

Cardamine amara, $L$. resedifolia, $L$. alpina, Willd.

Draba aizoides, $L$. tomentosa, Wahlenb.

Biscutella lavigata, $L$.

Futchinsia alpina, $R$. brown.

Polygala vulgaris, $L$.
Gentiana lutea, $L$.

punctata, $L$.

cruciata, $L$.

asclepiadea, $L$.

acaulis, $L$.

excisa, Presl.

verna, $L$.

bavarica, $L$.

bavarica subacanlis, $L$.

brachyphylla, Vill.

nivalis, $L$

utriculosa, $L$.

campestris, $L$

campestris (alba).

obtusifolia, Willd.

tenella, Rotböll (=gla(ialis, Thom.)

ciliata, $L$.

Convolvulus arvensis, $L$

Cuscuta Epithymum, $L$.

Solanum Dulcanarn, $L$.

Linaria alpina, Mill.

Veronica aphylla, $L$

latifolia, $L$

chamzdrys, $L$.

officinalis, $L$

alpina, $L$.

saxatilis, Jacq.

bellidioides, $L$

pedicularis palustris, $L$.

rostrata, $L$

verticillata, $L$

incarnata-tuberosa, Caviezel.

atrorubens, Schleisher.

Alectorolophus minor, Eber. (= Rhinanthus cristagalli, $L$.)

Euphrasia officinalis, $L$. minima, Schleich.

Salvia glutinosa, $L$.

Thymus Serpyllum, $L$.

Calamintha Acinos, Clairville.

Dracocephalum Ruyschiana, $L$.

Prunella grandiflora, $l$.

Teucrium montanum (supinuns), $L$.

Echium vulgare, $L$.

Myosotis sylvatica alpestris, Iloffm.

Eritrichium nanum, schrad.

Androsace chamæjasme, IIost. (not Wulf.)

obtusifolia, All.

glacialis, Hoppe.

Primula farinosa, $L$.

villosa, Jacq.

latifolia, Lapeyouse.

riscosa, $D C$

integrifolia, $L$

Soldanella alpina, $L$.

pusilla, Baumg.

Pinguicula vulgaris, $L$.

Plantago alyina, $L$. media, $L$.

Calluna vulgaris, Sulisb.

Azalea procumbens, $L$.

Rirododendron ferrugineum, $L$.

Vaccinium Vitis Idxa, $L$

Pyrola (Ramischia Opiz.) secunda, $L$. unifiora, $L$.

Fuphorbia cyparissias, $L$.

Geranitum sanguineum, $L$, 
Plytemma hemispharienm, $L$. humile, Schleich.

pauciflorum, $L$. orbiculare, $L$.

Campanula pusilla, Hänk. rotundifolia, $L$.

rapunculoides, $L$.

Trachelium, $L$.

thyrsoidea, $L$.

barbata, $L$.

Epilobium angustifolium, $L$

Fleischeri, Hochstetter.

montanum (collinurn), $L$. organifolium, Lam. (=alsinefol : Vill. $)$ alpinum, $L$.

Ononis repens, $L$.

Medicago falcata, $L$. lupulina, $L$.

Melilotus officinalis, Desronsseaux.

Trifolium pratense, $L$. medium, $L$. alpinum, $L$. cespitosum, Regnier. badium, Schreber.

Phaca astragalina, $D C$.

Oxytropis campestris, $I C$.

Hippocrepis comosa, $L$.

Hedysarum obscurum, $D C$.

Onobrychis sativa, Lam. arenaria, $D C$

Vicia cracca, $L$. Sepium, $L$.

Alchemilla vulgaris, $L$. (subsericea). alpina.

Dryas octopetala, $L$.

Geum montanum, $L$ reptans, $L$.

Fragaria vesca, $L$.

Potentilla anserina, $L$. argentea, $\boldsymbol{L}$ 'Tormentilla, Sibtherb aurea, $L$

Rosa alpina, L.

Sedum annuum, $L$. villosum, $L$

dasyphyllum, $L$.

acre, $L$.

Sempervivum Wulfeni, Hoppe.

montanum, $L$.

arachnoideum, $L$.
Sempervivum Braunii, Funk.

Saxifraga Aizoon, Jacq.

cæsia, $L$.

oppositifolia, $L$.

aspera, $L$.

bryoides, $L$.

aizoides, $L$.

stellaris, $L$.

Clusii, Gauan.

planifolia, Lapeyr.

exarata, Vill.

muscoides (compacta), Wulfen.

stenopetala, Goud.

Seguieri, Spreng.

Astrantia minor, $L$.

Bupleurum stellatum, $L$.

Meum Mutellina, Gärtner.

Iinnea borealis, $L$.

Valeriana tripteris, $L$. tripteris (integrifolia), $L$.

Knautia sylvatica, Dub.

Scabiosa columbaria, $L$

Adenostyles albifrons, Reichb. hybrida, $D C$.

Aster alpinum, $L$.

Bellis perennis, $L$

Erigeron uniflorus, $L$ alpinus, $L$.

Inula montana, $L$.

Gnaphalium sylvaticum, $L$.

Hoppeanum, Koch.

Leontopodium.

dioicum, $L$.

Achillea nana, $L$.

moschata, Wulfen.

atrata, $L$.

millefolium, $L$.

Chrysanthemum leucanthemum, $L$. alpinum, $L$.

Aronicum scorpioides, Koch.

Senecio cordatus, Koch.

viscosus, $L$.

abrotanifolius, $L$.

carniolicas, Willd.

saracenicus, $L$.

Doronicum, $L$

Cirsium acaule, $A l l$.

Carlina acaulis, $L$.

Crepis aurea, Cassin.

Hieracium Pilosella, $L$.

On the Exact Measurement of Trees. (Part 4.) The InAuence of the unfavourable Season of 1879 on the Growth of Trees. By Sir R. Christison, Bart.

(Read 8th January 1880.)

It was my hope and intention to present at the present time, in continuation of former notes on the "Exact Measurement of Trees," a contribution of facts relative to the growth of the common oak in this country. I have already accumu- 